\title{
Racial Barrier Socialization and the Well-Being of African American Adolescents: The Moderating Role of Mother-Adolescent Relationship Quality
}

\author{
Shauna M. Cooper \\ University of South Carolina
}

\author{
Vonnie C. McLoyd \\ University of Michigan
}

\begin{abstract}
Racial socialization has been suggested as an important factor in helping African American adolescents cope effectively with racism and discrimination. Although multiple studies have reported a positive link between racial pride socialization and psychological adjustment among African American youth, assessments of the association between adolescent adjustment and another dimension of racial socialization-racial barrier socialization-have yielded inconsistent findings. Using a sample of 190 African American adolescents, the present study focuses on the quality of mother-adolescent relationships as an indicator of affective context, and examines its moderating influence on the association between racial barrier socialization and adolescent adjustment. Regression analyses indicated that the link between racial barrier socialization and adolescent adjustment is moderated by mother-adolescent relationship quality. However, these associations varied by gender.
\end{abstract}

Racial discrimination is a risk factor for diminished psychological and behavioral functioning (e.g., depressive symptoms, risk behaviors, lower selfesteem) in African American children and adolescents (Brody et al., 2006; Caldwell, Kohn-Wood, Schmeelk-Cone, Chavous, and Zimmerman, 2004; Cooper, McLoyd, Wood, \& Hardaway, 2008; Fisher, Wallace, \& Fenton, 2000; Wong, Eccles, \& Sameroff, 2003). In line with risk and resilience frameworks (e.g., Garmezy, Masten, \& Tellegen, 1984; Luthar, Cicchetti, \& Becker, 2000; Masten, 2001), research has suggested that racial socialization both buffers the deleterious effects of racial discrimination (protective mechanism) and promotes positive adjustment (compensatory mechanism, e.g., Neblett, Philip, Cogburn, \& Sellers, 2006). Although there are multiple agents of racial socialization, extant research on racial socialization has focused almost

During the course of this research, the first author was supported by a postdoctoral fellowship from the Training Program in Research on Black Child Development (T32-HD049325-01, Vonnie C. McLoyd, Director), National Institute of Child Health and Human Development. Collection of the data on which the present study is based was supported by grant R01MH44662 from the National Institute of Mental Health and a faculty scholar award in child mental health from the William T. Grant Foundation, both awarded to the second author. We express our appreciation to all the families who participated in this study. We also gratefully acknowledge three anonymous reviewers for comments on this manuscript.

Requests for reprints should be sent to Shauna M. Cooper, Department of Psychology, University of South Carolina, 554 Barnwell College, Columbia, SC 29208. E-mail: smcooper@sc.edu exclusively on parents' communication of these messages. Studies indicate that a sizeable number of African American parents report racially socializing their children (Coard, Wallace, Stevenson, \& Brotman, 2004; Hughes \& Johnson, 2001; Hughes et al., 2006; Thornton, Chatters, Taylor, \& Allen, 1990). However, these percentages vary by the particular dimension of racial socialization in question (e.g., race pride, race barrier), as well as contextual (e.g., neighborhood racial composition) and demographic characteristics (e.g., parent education, race, ethnicity; e.g., Bowman \& Howard, 1985; Brown, Tanner-Smith, Lesane-Brown, \& Ezell, 2007; Hughes \& Chen, 1997; Thornton et al., 1990).

Two of the most common dimensions of racial socialization examined in empirical studies are racial pride socialization and racial barrier socialization (Cooper \& Smalls, 2010; Dotterer, McHale, \& Crouter, 2009; Hughes \& Chen, 1997; Marshall, 1995; Phinney \& Chavira, 1995; Stevenson, Cameron, Herrero-Taylor, \& Davis, 2002; Thornton et al., 1990). Racial pride socialization consists of messages about African American cultural heritage, ancestry, and history, and practices intended to promote cultural customs and traditions and instill cultural and racial pride. In contrast, racial barrier socialization is distinguished by messages and practices intended to promote children's awareness

(C) 2011 The Authors

Journal of Research on Adolescence (C) 2011 Society for Research on Adolescence DOI: $10.1111 / j .1532-7795.2011 .00749 . x$ 
of and ability to cope effectively with racial discrimination (Hughes \& Chen, 1997).

The association between racial barrier socialization and youth adjustment has been equivocal. Some studies have found no direct link (e.g., Constantine \& Blackmon, 2002; Cooper \& Smalls, 2010; Neblett et al., 2006), whereas others link socialization messages about racism and discrimination to negative psychological and educational outcomes (e.g., achievement outcomes; Marshall, 1995). Still others have found that racial barrier socialization is associated with positive psychological well-being and school adjustment among African American youth (Bowman \& Howard, 1985; Dotterer et al., 2009; Fischer \& Shaw, 1999; Sanders, 1997; Scott, 2003, 2004; Stevenson, Reed, Bodison, \& Bishop, 1997). For example, Scott (2003, 2004) suggested that African American high school students whose parents reportedly transmitted more racial barrier messages were more likely to use positive coping strategies (e.g., problem solving skills, seeking social support) to deal with a discriminatory situation.

The strength and nature of the link between racial barrier socialization and psychological adjustment may be conditional on a number of factors not examined in prior research, resulting in a discordant pattern of findings. The present study focuses on one of these potential moderating factors. Specifically, we examine the extent to which the quality of mother-adolescent relationships influences the strength of the link between racial barrier socialization and adolescent adjustment in a sample of single-parent African American families. Our study is informed by Darling and Steinberg's (1993) integrative model of parenting, which posits that the effect of a particular parenting practice (e.g., involvement, deprivation of privilege) on youth adjustment depends partly on the parenting style (e.g., warmth, conflict) within which that practice occurs. In the present study, we conceptualize mother-adolescent relationship quality as a marker of parenting style, and assume that it will moderate the effect of racial barrier socialization as a specific parenting practice. Recent research lends empirical support for Darling and Steinberg's claim about the moderating influence of parenting style (e.g., Simpkins, Weiss, McCartney, Kreider, \& Dearing, 2006), but the present study is the first to use this framework to better understand variation in the link between racial barrier socialization and adolescent adjustment.

We expected that racial barrier messages conveyed within the context of a warm and supportive mother-adolescent emotional climate would predict higher levels of adolescent adjustment, whereas those conveyed within the context of a less satisfying mother-adolescent emotional climate were expected to predict lower levels of adolescent adjustment. Although racial barrier messages are thought to be an important mechanism for conveying strategies to deflect or otherwise effectively cope with experiences of racial discrimination, these same messages may adversely affect adolescents' psychological and school outcomes when mother-adolescent relationships are less warm and harmonious. Racial barrier socialization that is not communicated within the context of a supportive and encouraging environment may reduce adolescents' sense of control over their environment or self-efficacy, which in turn, may lead to less positive indicators of psychological well-being. Prior research suggests that the affective context of racial barrier socialization is an important consideration (e.g., Coard, Wallace, Stevenson, \& Brotman, 2004; Frabutt, Walker, \& Mackinnon-Lewis, 2002; Hughes et al., 2006). In addition, recent research indicates that democratic and engaged parenting moderates the association between racial barrier socialization and African American adolescents' school engagement (Smalls, 2009). To date, no study has examined whether parent-adolescent relationship quality (e.g., supportiveness; closeness) moderates the association between racial barrier socialization and psychological well-being.

In addition to assessing the moderating role of mother-adolescent relationship quality in the association between racial barrier socialization and adolescent well-being, the present study assesses whether this hypothesized moderation holds for both boys and girls. This question is prompted by evidence that parents transmit differential racial socialization messages to sons and daughters (e.g., Bowman \& Howard, 1985; Brown, Linver, \& Evans, 2009; Hughes, Hagelskamp, Way, \& Foust, 2009; Thomas \& Speight, 1999) and that gender influences the strength of the relationship between racial barrier socialization and adolescent functioning (e.g., Davis \& Stevenson, 2006).

\section{METHOD}

\section{Participants}

The sample was drawn from a study designed to assess the influence of maternal employment and job loss on family processes among African American single mothers and their adolescent children 
residing in a Midwestern urban city. It consists of 190 mothers $(M=37.5 ; S D=8.07)$ and children aged $12-16$ years $(M=14.09 ; S D=0.94)$. Forty-five percent of the adolescents were female. At the time of the interview, $61 \%$ of the sample received public assistance from Aid to Families with Dependent Children.

\section{Procedure}

Families were selected to participate in the original study if the mother or female legal guardian of the focal child was not currently married (e.g., never married, divorced, separated, widowed) and not living with a partner. Mothers and focal children were interviewed in their homes. The average time of the mother interview was 2 hours, while the child interview took about 1 hour and 20 minutes. Two interviewers worked as a team, with one interviewing the mother and the other interviewing the child. Upon completion of the interview, mothers were paid \$25 and focal children were paid \$10.

\section{Measures}

Racial barrier socialization. Racial barrier socialization was assessed with three items. Mothers indicated on a 5 -point scale $(1=$ never; $5=$ very often) how often they discuss [with focal child] "the difficulties your child will face because he/she is black," "how to deal with racism and racial discrimination," and "race and how it affects the opportunities people are given." Reliability for this scale was 0.85. Higher scores indicate more discussion of racism/discrimination and potential racial barriers.

Relationship with mother. The measure of the quality of mother-adolescent relationships was based on adolescent report and consisted of 12 items adapted from Swanson's Parent-Child Relations Scale (1950). Using a 5-point scale $(1=$ not true at all; 5 = very true), the adolescent indicated how well each statement characterized relationships with his/her mother (e.g., my mother tries to understand my problems and worries; I feel close to my mother; I talk over important plans with my mother). Reliability was 0.92 , with higher scores indicating more positive relationships with the mother.

\section{Adolescent Well-Being}

Depressive symptoms. Level of depressive symptomatology was measured with 12 items from Birleson's (1981) Self-Rating Scale of Depression.
Statements indicating the presence of various symptoms of depression were read to the adolescent, who then indicated on a 5 -point scale $(1=$ not true at all, 5 = very true) how true each statement was of him/her during the past week (e.g., I feel so sad I can hardly stand it; I feel like crying). Reliability was 0.72 . Higher scores indicate greater depressive symptomatology.

Self-esteem. Rosenberg's (1965) Self-Esteem Scale assessed adolescents' feelings of individual selfworth (10 items; e.g., I take a positive attitude toward myself). The scale ranged from 1 (not true at all) to 5 (very true). Higher scores indicate more positive selfesteem. Reliability for this scale was 0.74 .

\section{Control Variables}

Because of gender differences in racial barrier socialization (e.g., Bowman \& Howard, 1985), gender is taken into account in all analyses. Similarly, because maternal education has been associated with racial socialization (e.g., Thornton et al., 1990) and because age differences have been found in both racial socialization (e.g., Hughes \& Chen, 1997) and quality of mother-adolescent relationships (e.g., Brody \& Flor, 1998), maternal education and adolescent age were included as control variables in all analyses.

\section{RESULTS}

Correlations, means, and standard deviations for all study variables are shown in Table 1. To examine the contribution of mother-adolescent relationship quality and racial barrier socialization to adolescents' psychological well-being, we conducted two separate hierarchical linear regression analyses, one model predicting self-esteem and the other predicting depressive symptomatology. Control variables were entered into the equation at step 1 , followed by racial barrier socialization and mother-adolescent relationship at step 2. Although the interaction between racial barrier socialization and mother-adolescent relationship was the main interaction (2-way) of interest, all possible interactions were entered into step 3 to correctly specify the regression model. As gender has been linked to racial barrier socialization (e.g., Bowman \& Howard, 1985; Thomas \& Speight, 1999), a threeway interaction among gender, racial barrier socialization, and mother-adolescent relationship quality (Gender $\times$ Racial Barrier Socialization $\times$ MotherAdolescent Relationship) was also included in step 
TABLE 1

Correlations, Means, and Standard Deviations of All Study Variables for Males $(N=111)$ and Females $(N=79)$

\begin{tabular}{|c|c|c|c|c|c|c|c|}
\hline & & 1 & 2 & 3 & 4 & 5 & 6 \\
\hline \multicolumn{8}{|c|}{ Demographic Variables } \\
\hline 1. & Age & - & $0.23^{*}$ & $0.19^{*}$ & $0.21^{*}$ & 0.08 & -0.04 \\
\hline 2. & Mother's Level of Education & 0.00 & - & 0.11 & 0.06 & $0.17^{+}$ & -0.08 \\
\hline \multicolumn{8}{|c|}{ Predicator Variables } \\
\hline 3. & Racial Barrier Socialization & 0.14 & -0.02 & - & 0.14 & 0.06 & -0.04 \\
\hline 4. & Relationship w/Mother & 0.14 & 0.10 & 0.07 & - & $0.33^{* *}$ & $-0.41^{* *}$ \\
\hline \multicolumn{8}{|c|}{ Adolescent Well-Being } \\
\hline 5. & Self-Esteem & -0.05 & 0.13 & 0.06 & $0.62^{* *}$ & - & $-0.42^{* *}$ \\
\hline 6. & Depressive Symptoms & -0.16 & -0.13 & $-0.26^{*}$ & $-0.57^{* *}$ & $-0.60^{* *}$ & - \\
\hline \multirow[t]{2}{*}{ Girls } & Mean & $13.99^{\mathrm{a}}$ & 1.99 & 3.45 & 3.91 & 3.99 & $1.48^{\mathrm{b}}$ \\
\hline & Standard deviation & 1.02 & 0.89 & 0.73 & 0.59 & 0.67 & 0.31 \\
\hline \multirow[t]{2}{*}{ Boys } & Mean & $14.25^{\mathrm{a}}$ & 2.27 & 3.37 & 3.80 & 4.09 & $1.37^{\mathrm{b}}$ \\
\hline & Standard deviation & 0.85 & 1.01 & 0.89 & 0.69 & 0.54 & 0.24 \\
\hline
\end{tabular}

Note. Correlation coefficients for females are below the diagonal. ${ }^{\mathrm{a}, \mathrm{b}}$ Means sharing a common superscript are significantly different. ${ }^{\dagger} p<.10 ;{ }^{*} p<.05 ;{ }^{* *} p<.01$.

4. All continuous variables were centered and significant moderating relationships were explored using Aiken and West's (1991) guidelines for interpreting interactions (e.g., one standard deviation above/below mean) and plotted using Sibley's (2008) utility for examining interactions in multiple regression.

\section{Self-Esteem}

As shown in Table 2, racial barrier socialization was not directly related to self-esteem $(B=.04, n s)$. However, consistent with previous research (e.g., Laursen, Furman, \& Mooney, 2006), more positive mother-adolescent relationships predicted higher self-esteem $(B=.41 ; p<.001)$.

Although none of the two-way interactions were significant, the three-way interaction of gender, racial barrier socialization, and mother-adolescent relationship quality was significant $(B=.34$; $p<.05$ ). Plotting of this interaction indicated that when mother-adolescent relationship quality was lower, more frequent discussion of racial barriers predicted higher self-esteem among girls (see Figure 1). However, when mother-daughter relationship quality was higher, increased racial barrier socialization was associated with lower self-esteem. Among boys, the quality of mother-adolescent relationships did not moderate the association between frequency of racial barrier messages and self-esteem.

\section{Depressive Symptoms}

Similar to the pattern found for self-esteem, racial barrier socialization was not directly associated with adolescents' report of depressive symptoms $(B=-.04, n s)$. More positive mother-adolescent relationships predicted lower depressive symptomatology $(B=-.17 ; p<.001)$. Similar to the findings for self-esteem, the three-way interaction of gender, racial barrier socialization, and mother-adolescent relationship quality was significant $(B=-.23$; $p<.001)$. As shown in Figure 2, when girls perceived less positive relationships with their mother, increased racial barrier socialization was associated with lower depressive symptomatology. Among girls who perceived a more positive relationship with their mother, however, increased racial barrier socialization was associated with higher depressive symptomatology. Among boys, mother-adolescent relationship quality did not moderate the link between racial barrier socialization and depressive symptomatology.

\section{DISCUSSION}

In the present study, the quality of mother-adolescent relationships emerged as a robust predictor of adolescents' psychological functioning - a finding in accord with numerous existing studies of African American adolescents (e.g., Barber, Ball \& Armistead, 2003; Brody et al., 2005; Lamborn, Mounts, Steinberg, \& Dornbusch, 1991). Adolescents' psychological well-being was not directly related to racial barrier socialization, but in keeping with our expectations and Darling and Steinberg's (1993) claim that parenting style influences the effects of parenting behavior, the link between racial barrier socialization and adolescent functioning was conditional on both the affective quality of 
TABLE 2

Hierarchical Regression Model Predicting African American Adolescents' Self-Esteem and Depressive Symptoms $(N=188)$

\begin{tabular}{|c|c|c|}
\hline & Self-Esteem & Depressive Symptoms \\
\hline \multicolumn{3}{|l|}{ Step 1} \\
\hline Age & $0.01(0.05)$ & $-0.03(0.02)$ \\
\hline Mother's Education Level & $0.10(0.05)^{*}$ & $-0.03(0.02)$ \\
\hline Gender $(1=$ Female; 2 = Male $)$ & $-0.04(0.09)$ & $-0.11(0.04)^{* *}$ \\
\hline$\Delta R^{2}$ & 0.01 & 0.05 \\
\hline$F$-statistic & 1.68 & $4.38^{* *}$ \\
\hline \multicolumn{3}{|l|}{ Step 2} \\
\hline Age & $0.00(0.05)$ & $-0.02(0.02)$ \\
\hline Mother's Educational Level & $0.09(0.04)^{*}$ & $-0.03(0.02)$ \\
\hline Gender & $-0.04(0.09)$ & $-0.11(0.04)^{* *}$ \\
\hline Racial Barrier Socialization & $0.04(0.05)$ & $-0.04(0.02)$ \\
\hline$\Delta R^{2}$ & 0.00 & 0.01 \\
\hline$F$-statistic & 1.40 & $3.97^{* *}$ \\
\hline \multicolumn{3}{|l|}{ Step 3} \\
\hline Age & $-0.04(0.05)$ & $-0.01(0.02)$ \\
\hline Mother's Educational Level & $0.09(0.04)^{*}$ & $-0.02(0.02)$ \\
\hline Gender & $-0.07(0.08)$ & $-0.10(0.04)^{* *}$ \\
\hline Racial Barrier Socialization & $0.00(0.05)$ & $-0.02(0.02)$ \\
\hline Relationship with Mother & $0.41(0.06)^{* *}$ & $-0.17(0.03)^{* * *}$ \\
\hline$\Delta R^{2}$ & 0.18 & 0.16 \\
\hline F-statistic & $10.10^{* * *}$ & $11.79^{* * *}$ \\
\hline \multicolumn{3}{|l|}{ Step 4} \\
\hline Age & $-0.04(0.05)$ & $-0.01(0.02)$ \\
\hline Mother's Educational Level & $0.09(0.04)^{*}$ & $-0.03(0.02)$ \\
\hline Gender & $-0.09(0.08)$ & $-0.09(0.03)^{* *}$ \\
\hline Racial Barrier Socialization & $0.03(0.15)$ & $-0.12(0.06)^{\dagger}$ \\
\hline Relationship with Mother & $0.22(0.20)$ & $-0.28(0.08)^{* *}$ \\
\hline Racial Barrier Social. × Gender & $-0.02(0.10)$ & $0.06(0.04)$ \\
\hline Mother-Adol. Relat' $\mathrm{p} \times$ Gender & $0.14(0.13)$ & $0.07(0.06)$ \\
\hline Racial Barrier Social. $\times$ Mother-Adol. Relat'p & $0.12(0.08)$ & $0.01(0.04)$ \\
\hline$\Delta R^{2}$ & 0.00 & 0.01 \\
\hline F-statistic & $6.70^{* * *}$ & $7.93^{* * *}$ \\
\hline \multicolumn{3}{|l|}{ Step 5} \\
\hline Age & $-0.04(0.05)$ & $-0.01(0.02)$ \\
\hline Mother's Educational Level & $0.09(0.04)^{*}$ & $-0.03(0.02)$ \\
\hline Gender & $-0.12(0.08)$ & $-0.08(0.04)^{*}$ \\
\hline Racial Barrier Socialization & $0.01(0.15)$ & $-0.10(0.07)$ \\
\hline Relationship with Mother & $0.17(0.19)$ & $-0.25(0.09)^{* * *}$ \\
\hline Racial Barrier Social. $\times$ Gender & $-0.01(0.09)$ & $0.05(0.04)$ \\
\hline Mother-Adol. Relat' $\mathrm{p} \times$ Gender & $0.20(0.13)$ & $0.03(0.06)$ \\
\hline Racial Barrier Social. $\times$ Mother-Adol. Relat'p & $-0.43(0.26)$ & $0.36(0.11)^{* *}$ \\
\hline Race Barr $\times$ Mother-Adol. Relat' $p \times$ Gender & $0.34(.16)^{*}$ & $-0.23(.07)^{* * * *}$ \\
\hline$\Delta R^{2}$ & 0.03 & 0.04 \\
\hline$F$-statistic & $6.63^{* * *}$ & $8.70^{* * *}$ \\
\hline Total Adjusted $R^{2}$ & 0.22 & 0.27 \\
\hline
\end{tabular}

${ }^{*} p<.05 ;{ }^{* *} p<.01 ;{ }^{* * *} p<.001 ;{ }^{\dagger} p<.10$

To correctly specify the model, all possible two-way interactions were entered in the model.

mother-adolescent relationships and adolescent gender. However, the pattern of these relationships differed from our original hypotheses. In particular, we found a consistent pattern among girls indicating that increased racial barrier socialization messages conveyed in the context of less positive mother-adolescent relationship predicted lower depressive symptomatology and higher self-esteem. Thus, when low on one dimension, the other dimension acted as a counterbalance and was associated with more positive psychological well-being. However, in the context of a more positive mother-daughter relationship, we found that increased racial barrier socialization was associated 


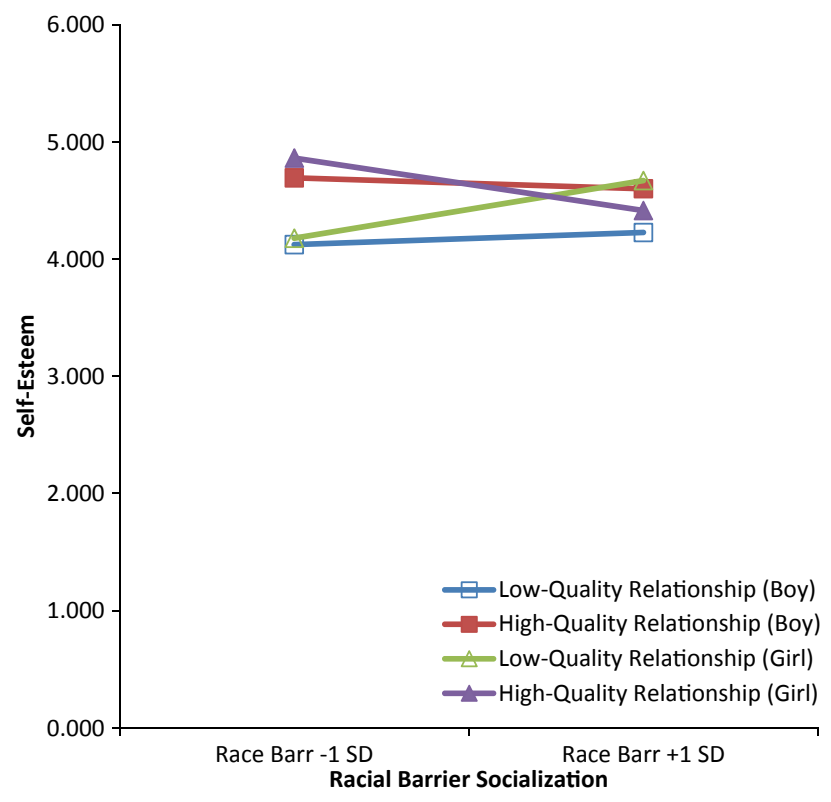

FIGURE 1 Significant interaction between frequency of racial barrier socialization and mother-adolescent relationship quality predicting self-esteem.

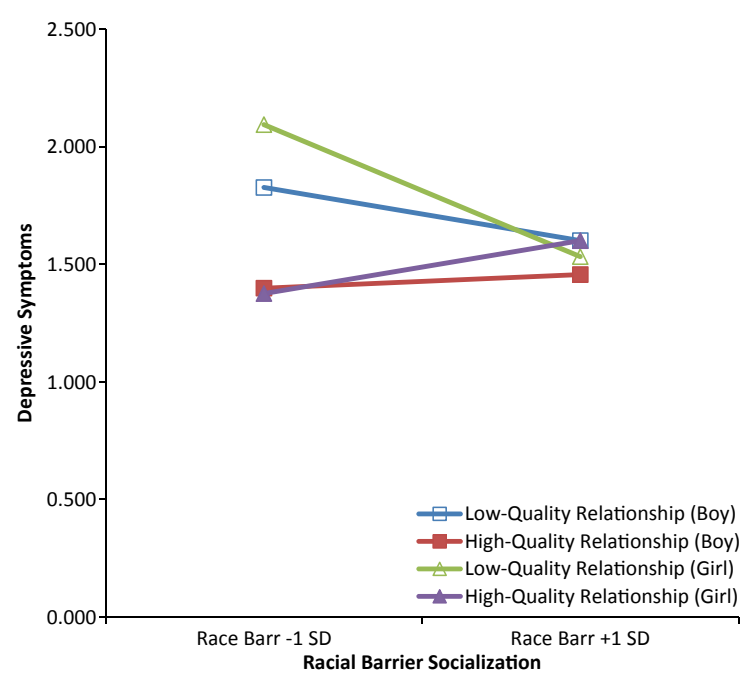

FIGURE 2 Significant interaction between frequency of racial barrier socialization and mother-adolescent relationship quality predicting depressive symptoms.

with more negative psychological outcomes for girls. It is plausible that, in conjunction with a more positive mother-adolescent relationship, moderate levels of racial barrier socialization may facilitate greater psychological well-being among African American girls. Recent studies support this notion with indications that racial barrier socialization may affect African American youth outcomes in a curvilinear fashion (Harris-Britt, Valrie, KurtzCostes, \& Rowley, 2007).
We saw no such moderating relationship among boys. Gender, then, appears to influence whether the quality of mother-adolescent relations condition adolescents' response to racial barrier messages and the nature of that response. These findings, together with evidence that adolescent gender influences the frequency with which racial barrier messages are transmitted (Bowman \& Howard, 1985; Brown et al., 2010; Thomas \& Speight, 1999) as well as adolescents' response to racial barrier messages (Davis \& Stevenson, 2006), point to the complex ways in which adolescent gender and the larger affective context may figure into the racial socialization process. Although we offer no concrete explanations for these gender differences, we do suggest that these findings may reflect differences in male and female adolescents' sensitivity to the maternal parenting environment. In particular, the emotional climate or affective context in which racial barrier socialization is communicated may be particularly important for girls' psychological functioning. These findings are supported further by existing theoretical and empirical research suggesting that relational factors are particularly consequential to girls' psychological well-being (Corneille, Ashcraft, \& Belgrave, 2005; Gilligan, 1982; Taylor, Gilligan, \& Sullivan, 1995). In fact, studies have indicated that girls receive greater disclosure from their mothers as well as have increased sensitivity to maternal relationships (Dolgin, 1996; Gore, Aseltine, \& Colten, 1993). Thus, our findings may suggest that racial barrier socialization within the larger parenting context is an important consideration for African American girls' psychological well-being. Recent studies have supported this claim with indications that girls' outcomes may be more strongly associated with maternal racial socialization (e.g., Hughes et al., 2009).

We found that this pattern did not exist for African American boys. This is not to suggest that parental relationship quality is not a lens for examining the association between racial barrier socialization and boys' psychological well-being. It is possible that gender of parent is an important consideration (see McHale et al., 2006). Inclusion of paternal relationship quality might have yielded similar patterns for African American adolescent boys, as previous studies have suggested the importance of father-son relationships on boys' developmental and health outcomes (e.g., Caldwell et al., 2004). Multi-method studies may provide further insights into the gendered nature of racial socialization, which is of particular importance given the distinctive social experiences of African American boys and girls. 
Although this investigation advances the existing literature on racial barrier socialization and its relationship with adolescent well-being, it has limitations. First, the sample was comprised only of single mothers and their adolescent children. The stressors associated with being a single parent may have a role in the manner that racial barrier messages are communicated in the household. Second, because our sample was composed of primarily low-income families, the findings cannot be generalized to adolescents from more affluent backgrounds. Future studies are needed to determine how the relationships examined in the present study vary as a function of family configuration (e.g., two-parent households) and social class backgrounds. In addition to the previously discussed future directions, studies that examine how messages regarding potential encounters with racial discrimination are communicated and the context within which they are delivered would advance our understanding of how these messages influence psychological adjustment, particularly those that follow adolescents through the transition to adulthood. Also, future research studies should explore additional moderators of the link between racial barrier socialization and adolescent wellbeing. Notwithstanding these limitations, this study contributes to the existing literature surrounding race-specific socialization in African American households and proffers new directions for future research. In particular, this investigation suggests that the link between racial barrier socialization and psychological adjustment may be complex, in that these associations may be moderated by both child characteristics (e.g., gender) and context (e.g., mother-adolescent relationship).

\section{REFERENCES}

Aiken, L. S., \& West, S. G. (1991). Multiple regression: Testing and interpreting interactions. Newbury Park, CA: Sage.

Barber, C. N., Ball, J., \& Armistead, L. (2003). Postadolescent relationship and adolescent psychological functioning among African-American adolescents: Self-esteem as a mediator. Journal of Child and Family Studies, 12(3), 361-374.

Birleson, P. (1981). The validity of depressive disorder in childhood and the development of a self-rating scale: A research report. Journal of Child Psychology and Psychiatry, 22(1), 73-88. doi:10.1111/j.1469-7610.1981. tb00533.x

Bowman, P. J., \& Howard, C. (1985). Race-related socialization, motivation, and academic achievement: A study of Black youths in three-generation families.
Journal of the American Academy of Child Psychiatry, 24, 134-141. doi:10.1016/S0002-7138(09)60438-6

Brody, G. H., \& Flor, D. L. (1998). Maternal resources, parenting practices, and child competence, in rural, single-parent African American families. Child Development, 69(3), 803-816. doi:10.2307/1132205

Brody, G. H., Chen, Y., Murry, V. B., Ge, X., Simons, R., Gibbons, F., et al. (2006). Perceived discrimination and the adjustment of African American youths: A fiveyear longitudinal analysis with contextual moderation effects. Child Development, 77(5), 1170-1189. doi:10.1111/j.1467-8624.2006.00927.x

Brody, G. H., Murry, V. M., McNair, L., Chen, Y., Gibbons, F. X., Gerrard, M., et al. (2005). Linking changes in parenting to parent-child relationship quality and youth self-control: The strong African American families program. Journal of Research on Adolescence, 15(1), 47-69. doi:10.1111/j.1532-7795.2005.00086.x

Brown, T. L., Linver, M. R., et al. (2010). The role of gender in the racial and ethnic socialization of African American adolescents. Youth and Society, 41(3), 357-381.

Brown, T. L., Linver, M. R., Evans, M., \& DeGennaro, D. (2009). African American parents' racial and ethnic socialization and adolescent academic grades: Teasing out the role of gender. Journal of Youth and Adolescence, 38, 214-227.

Brown, T., Tanner-Smith, E., Lesane-Brown, C., \& Ezell, M. (2007). Child, parent, and situational correlates of ethnic/racial socialization. Journal of Marriage and Family, 69(1), 14-25. doi:10.1111/j.1741-3737.2006.00340.x

Caldwell, C., Kohn-Wood, L., Schmeelk-Cone, K., Chavous, T., \& Zimmerman, M. (2004). Racial discrimination and racial identity as risk or protective factors for violent behaviors in African American young adults. American Journal of Community Psychology, 33(1-2), 91105. doi:10.1023/B:AJCP.0000014321.02367.dd

Caldwell, C., Wright, J., Zimmerman, M., Walsemann, K., Williams, D., \& Isichei, P. (2004). Enhancing adolescent health behaviors through strengthening non-resident father-son relationships: A model for intervention with African-American families. Health Education Research, 19(6), 644-656. doi:10.1093/her/cyg078

Coard, S. J., Wallace, S. A., Stevenson, H. G., \& Brotman, L. M. (2004). Towards culturally relevant preventive interventions: The consideration of racial socialization in parent training with African American families. Journal of Child and Family Studies, 13(3), 277-293. doi:10.1023/B:JCFS.0000022035.07171.f8

Constantine, M. G., \& Blackmon, S. M. (2002). Black adolescents' racial socialization experiences: Their relations to home, school and peer self-esteem. Journal of Black Studies, 32(3), 322-335. doi:10.1177/00234702032006004

Cooper, S. M., McLoyd, V., Wood, D., \& Hardaway, C. (2008). The mental health consequences of racial discrimination for African American adolescents. In S. Quintana \& C. McKown (Eds.), Handbook of race, racism and the developing child (pp. 278-312). Hoboken, NJ: Wiley. 
Cooper, S., \& Smalls, C. (2010). Culturally distinctive and academic socialization: Direct and interactive relationships with African American adolescents' academic adjustment. Journal of Youth and Adolescence, 39(2), 199212. doi:10.1007/s10964-009-9404-1

Corneille, M., Ashcraft, A., \& Belgrave, F. (2005). What's culture got to do with it? Prevention programs for African American adolescent girls. Journal of Health Care for the Poor and Underserved, 16(4, Suppl.B), 38-47. doi:10.1353/hpu.2005.0109

Darling, N., \& Steinberg, L. (1993). Parenting style as context: An integrative model. Psychological Bulletin, 113(3), 487-496. doi:10.1037/0033-2909.113.3.487

Davis, G., \& Stevenson, H. (2006). Racial socialization experiences and symptoms of depression among Black youth. Journal of Child and Family Studies, 15(3), 303317. doi:10.1007/s10826-006-9039-8

Dolgin, K. (1996). Parents' disclosure of their own concerns to their adolescent children. Personal Relationships, 3(2), 159-169. doi:10.1111/j.1475-6811.1996.tb00109.x

Dotterer, A., McHale, S., \& Crouter, A. (2009). Sociocultural factors and school engagement among African American youth: The roles of racial discrimination, racial socialization and ethnic identity. Applied Developmental Science, 13(2), 61-73.

Fischer, A. R., \& Shaw, C. M. (1999). African Americans' mental health and perceptions of racist discrimination: The moderating effects of racial socialization experiences and self-esteem. Journal of Counseling Psychology, 46(3), 395-407. doi:10.1037/0022-0167.46.3.395

Fisher, C. B., Wallace, S. A., \& Fenton, R. E. (2000). Discrimination distress during adolescence. Journal of Youth E Adolescence, 29(6), 679-695. doi:10.1023/ A:1026455906512

Frabutt, J. M., Walker, A. M., \& Mackinnon-Lewis, C. (2002). Racial socialization messages and the quality of mother/child interactions in African American families. Journal of Early Adolescence, 22(2), 200-217. doi:10.1177/0272431602022002004

Garmezy, N., Masten, A., \& Tellegen, A. (1984). The study of stress and competence in children: A building block for developmental psychopathology. Child Development, 55(1), 97-111. doi:10.2307/1129837

Gilligan, C. (1982). In a different voice: Psychological theory and women's development. Cambridge, MA: Harvard University Press.

Gore, S., Aseltine, R., \& Colten, M. (1993). Gender, socialrelational involvement, and depression. Journal of Research on Adolescence, 3(2), 101-125. doi:10.1207/ s15327795jra0302_1

Harris-Britt, A., Valrie, C., Kurtz-Costes, B., \& Rowley, S. (2007). Perceived racial discrimination and self-esteem in African American youth: Racial socialization as a protective factor. Journal of Research on Adolescence, 17 (4), 669-682.

Hughes, D., \& Chen, L. (1997). When and what parents tell children about race: An examination of race-related socialization in African American families. Applied
Developmental Science, 1(4), 200-214. doi:10.1207/ s1532480xads0104_4

Hughes, D., \& Johnson, D. (2001). Correlates in children's experiences of parents' racial socialization behaviors. Journal of Marriage and Family, 63(4), 981-995. doi:10.1111/j.1741-3737.2001.00981.x

Hughes, D., Rodriguez, J., Smith, E., Johnson, D., Stevenson, H., \& Spicer, P. (2006). Parents' ethnic/racial socialization practices: A review of research and directions for future study. Developmental Psychology, 42(5), 747-770. doi:10.1037/0012-1649.42.5.747

Hughes, D., Hagelskamp, C., Way, N., \& Foust, M. (2009). The role of mothers' and adolescents' perceptions of ethnic-racial socialization in shaping ethnicracial identity among early adolescent boys and girls. Journal of Youth and Adolescence, 38(5), 605-626. doi:10.1007/s10964-009-9399-7

Lamborn, S., Mounts, N., Steinberg, L., \& Dornbusch, S. (1991). Patterns of competence and adjustment among adolescents from authoritative, authoritarian, indulgent, and neglectful families. Child Development, 62(5), 1049-1065. doi:10.2307/1131151

Laursen, B., Furman, W., \& Mooney, K. (2006). Predicting interpersonal competence and self-worth from adolescent relationships and relationship networks: Variablecentered and person-centered perspectives. Merrill-Palmer Quarterly, 52(3), 572-600. doi:10.1353/mpq.2006. 0030

Luthar, S., Cicchetti, D., \& Becker, B. (2000). The construct of resilience: A critical evaluation and guidelines for future work. Child Development, 71(3), 543-562. doi:10.1111/1467-8624.00164

Marshall, S. (1995). Ethnic socialization of African American children: Implications for parenting, identity development, and academic achievement. Journal of Youth and Adolescence, 24(4), 377-396. doi:10.1007/BF01537187

Masten, A. (2001). Ordinary magic: Resilience processes in development. American Psychologist, 56(3), 227-238. doi:10.1037/0003-066X.56.3.227

McHale, S., Crouter, A., Kim, J., Burton, L., Davis, K., \& Dotterer, A., et al. (2006). Mothers' and fathers' racial socialization in African American families: Implications for youth. Child Development, 77(5), 1387-1402. doi:10.1111/j.1467-8624.2006.00942.x

Neblett, E., Philip, C., Cogburn, C., \& Sellers, R. (2006). African American adolescents' discrimination experiences and academic achievement: Racial socialization as a cultural compensatory and protective factor. Journal of Black Psychology, 32(2), 199-218. doi:10.1177/ 0095798406287072

Phinney, J. S., \& Chavira, V. (1995). Parental ethnic socialization and adolescent coping with problems related to ethnicity. Journal of Research on Adolescence, 5 (1), 31-53. doi:10.1207/s15327795jra0501_2

Rosenberg, M. (1965). Society and the adolescent self-image. Princeton, NJ: Princeton University Press.

Sanders, M. G. (1997). Overcoming obstacles: Academic achievement as a response to racism and discrimination. 
Journal of Negro Education, 66(1), 83-93. doi:10.2307/ 2967253

Scott, L. D. (2003). The relation of racial identity and racial socialization to coping with discrimination among African American adolescents. Journal of Black Studies, 33(4), 520-538.

Scott, L. D. (2004). Correlates of coping with perceived discriminatory experiences among African American adolescents. Journal of Adolescence, 27(2), 123-127.

Sibley, C. G. (2008). Utilities for examining interactions in multiple regression [computer software]. University of Auckland. http://www.psych.auckland.ac.nz/utilitiesfor-examining-interactions.xlsx

Simpkins, S., Weiss, H., McCartney, K., Kreider, H., \& Dearing, E. (2006). Mother-child relationship as a moderator of the relation between family educational involvement and child achievement. Parenting: Science and Practice, 6(1), 49-57. doi:10.1207/ s15327922par0601_2

Smalls, C. (2009). African American adolescent engagement in the classroom and beyond: The roles of mother's racial socialization and democratic-involved parenting. Journal of Youth and Adolescence, 38(2), 204213. doi:10.1007/s10964-008-9316-5

Stevenson, H., Cameron, R., Herrero-Taylor, T., \& Davis, G. (2002). Development of the Teenager Experience of Racial Socialization scale: Correlates of race-related socialization frequency from the perspective of Black youth. Journal of Black Psychology, 28(2), 84-106. doi:10.1177/0095798402028002002

Stevenson, H. C., Reed, J., Bodison, P., \& Bishop, A. (1997). Racism stress management: Racial socialization beliefs and the experience of depression and anger in African American youth. Youth and Society, 29(2), 197222. doi:10.1177/0044118X97029002003

Swanson, G. E. (1950). The development of an instrument for rating child-parent relationships. Social Forces, 29 (1), 84-90.

Taylor, J. M., Gilligan, C., \& Sullivan, A. (1995). Between voice and silence: Women and girls, race and relationship. Cambridge, MA: Harvard University Press.

Thomas, A. J., \& Speight, S. L. (1999). Racial identity and racial socialization attitudes of African American parents. Journal of Black Psychology, 25(2), 152-170. doi:10.1177/0095798499025002002

Thornton, M. C., Chatters, L. M., Taylor, R.J., \& Allen, W. R. (1990). Sociodemographic and environmental correlates of racial socialization by Black parents. Child Development, 61(2), 401-409. doi:10.1037/0893-3200.14.4.531

Wong, C., Eccles, J., \& Sameroff, A. (2003). The influence of ethnic discrimination and ethnic identification on African American adolescents' school and socioemotional adjustment. Journal of Personality, 71(6), 11971232. doi:10.1111/1467-6494.7106012 